\title{
Thrombosis in newborn infants
}

\author{
Viviana Bacciedoni, M.D. ${ }^{a, b}$, Myriam Attie, M.D. ${ }^{c}$, and Hugo Donato, M.D. ${ }^{d, e}$ \\ National Committee of Hematology, Oncology and Transfusion Medicine
}

\begin{abstract}
The incidence of thrombosis is higher among newborn infants than in any other stage of pediatric development. This fact is the consequence of labile characteristics of the neonatal hemostatic system, in addition to exposure to multiple risk factors and the wide use of vascular catheters. Venous thromboses, which mainly affect the limbs, the right atrium and renal veins, are more frequently seen than arterial thromboses. A stroke may be caused by the occlusion of the arterial flow entering the brain or by occlusion of its venous drainage system. Purpura fulminans is a very severe condition that should be treated as a medical emergency, and is secondary to severe protein $\mathrm{C}$ deficiency or, less frequently, protein $\mathrm{S}$ or antithrombin deficiency. Most thrombotic events should bemanaged with antithrombotic therapy, which is done with unfractionated and/or low molecular weight heparins. Purpura fulminans requires protein $C$ replacement and/or fresh frozen plasma infusion. Thrombolytic therapy is done using tissue plasminogen activator and should only be used for life-, or limb-, or organthreatening thrombosis.

Key words: thrombosis, newborn infant, heparin,
\end{abstract} anticoagulants, thrombolytic therapy.

a Hospital Pediátrico A Fleming, Department of Hematology.

b. Hospital L. Lagomaggiore, Neonatal Hematology

City of Mendoza,

Mendoza.

c. Hospital de Niños Ricardo Gutiérrez, Department of Hematology.

d. Pediatric Hematology Outpatient Offices.

City of Buenos Aires.

e. Hospital del Niño de San Justo, Division of Hematology and Oncology, San Justo, Buenos Aires.

E-mail address:

Hugo Donato, M.D.:

hcdonato@gmail.com

Funding:

None.

Conflict of interest:

None

Received: 7-28-2015

Accepted: 8-6-2015

\section{INTRODUCTION}

During the first month of life, the likelihood of thrombotic complications is 40 times higher than at any other pediatric age, especially in critically-ill children or those who have a central catheter in place. Catheterization is undoubtedly the most important risk factor for both arterial and venous thromboembolism. Approximately $90 \%$ of thromboembolic events are catheter-related. ${ }^{1,2}$ The presence of a catheter favors the occurrence of thrombosis by different mechanisms, either isolated or combined. Catheters may cause mechanical damage to the vascular wall and slowing or interruption of the blood flow, they are manufactured with potentiallythrombogenic material, or they are used to infuse agents that damage the vascular wall. ${ }^{3}$ Other predisposing factors include perinatal asphyxia, prematurity, heart conditions, sepsis, hypoxia, and maternal diabetes. Congenital prothrombotic disorders play an irrelevant role in this period. ${ }^{4}$

The overall incidence of thromboembolism in hospitalized newborn infants is approximately 2.4 per 1000 admissions. ${ }^{2,5}$ It has been reported that $1 \%$ of newborn infants with catheters have symptoms indicative of thrombosis, ${ }^{6}$ and it is estimated that the incidence of catheter-associated asymptomatic thrombosis is $20-30 \% .^{7-11}$

An adequate management of thrombosis is generally complicated due to the extrapolation of adult management techniques. However, over the past years, major differences related to age have been observed in this condition (epidemiology, diagnostic tests, pharmacokinetics of antithrombotic agents), which have favored the use of diagnostic and therapeutic procedures appropriate for this period in life.

\section{FEATURES OF THE HEMOSTATIC SYSTEM IN NEWBORN INFANTS}

The hemostatic system of newborn infants has a series of special characteristics different from that of adults, which make it especially labile. ${ }^{12} \mathrm{~A}$ reduced synthesis of several coagulation proteins (factors II, VII, IX, $X, X I$ and XII, high molecular weight kininogen, antithrombin III, proteins $S$ and $C)$, an altered function of other coagulation proteins (fibrinogen, plasminogen), an accelerated clearance of factors, and differences in platelet functioning are some of the specific differences between the hemostatic system of adults and newborn infants. In addition, both 
stimuli occurred during childbirth (acidosis, hypoxia, thermal changes, release of tissue factor) and a frequent exposure to trauma and manipulation result in a coagulation mechanism that is more active than that of adults. Although components of the hemostatic system start synthesizing during the tenth week of gestation and increase gradually, values reached at birth are remarkably different among them (Table 1). ${ }^{9,13-17}$

Below we present the most important information regarding coagulation factors in newborn infants: ${ }^{7,16,18-24}$

- Vitamin K-dependent factors (II, VII, IX, X) and contact factors (XII, XI, prekallikrein and high molecular weight kininogen) are reduced to varying degrees.

- Fibrinogen and factors V, VIII and XIII levels are similar to those of adults.

- Von Willebrand factor level is almost twice that of adults.

The time necessary for reduced factors to reach normal values is variable and may range from a few days to several months. ${ }^{14-16,19,25,26}$ Most factors reach $80 \%$ of the value of adults by six months old.

In addition, fibrinogen is quantitatively normal, but has qualitative differences because it has a higher sialic acid content and a shorter half life. ${ }^{27-30}$

In spite of these alterations, newborn infants maintain a hemostatic balance because natural inhibitors are also different from those of adults: $:^{13-15,19,25,26,31-35}$

- Antithrombin is reduced by $50 \%$, and proteins $\mathrm{C}$ and $\mathrm{S}$, by $60 \%$.

- Protein $S$ circulates absolutely freely (active form) because newborn infants lack C4b, a binding protein of protein $\mathrm{S}$.

- Alpha-2-macroglobulin is high, approximately twice the level of adults.

Fibrinolytic activity is also altered, with plasminogen levels reduced by $50 \%$.

Many of the above mentioned differences in the hemostatic system are even sharper among preterm infants.

TABLE 1. Normal average values of procoagulant, inhibitory and fibrinolytic factors at 24 hours of life and approximate time needed to reach normal values

\begin{tabular}{|c|c|c|c|}
\hline & $\begin{array}{c}\text { Term newborn } \\
\text { infant }\end{array}$ & $\begin{array}{c}\text { Preterm newborn } \\
\text { infant }\end{array}$ & $\begin{array}{l}\text { Time to achieve } \\
\text { a normal value }\end{array}$ \\
\hline \multicolumn{4}{|l|}{ Procoagulant: } \\
\hline Fibrinogen\# & 2.83 & 2.43 & At birth \\
\hline F. II & 0.48 & 0.45 & 2-12 months \\
\hline F. V & 0.72 & 0.88 & At birth \\
\hline F. VII* & 0.66 & 0.67 & 2-12 months \\
\hline F. VIII & 1.00 & 1.11 & At birth \\
\hline F. IX*\# & 0.53 & 0.35 & 3-9 months \\
\hline F. $X^{*}$ & 0.40 & 0.41 & 2-12 months \\
\hline F. $\mathrm{XI}^{* \#}$ & 0.38 & 0.30 & 1-2 months \\
\hline F. XII*\# & 0.53 & 0.38 & 9-14 days \\
\hline F. XIII* & 0.79 & 0.70 & 4-5 days \\
\hline Prekallikrein* & 0.37 & 0.33 & More than 6 months \\
\hline $\mathrm{HMWK}^{*}$ & 0.54 & 0.49 & 2-3 months \\
\hline Von Willebrand factor* & 1.53 & 1.36 & 5-6 months \\
\hline \multicolumn{4}{|l|}{ Inhibitory: } \\
\hline Antithrombin*\# & 0.63 & 0.38 & 3 months \\
\hline $\mathrm{A} 2 \mathrm{M} * \#$ & 1.39 & 1.1 & Adult \\
\hline Protein $C^{*} \#$ & 0.35 & 0.28 & 2-9 months \\
\hline Protein $S^{*} \#$ & 0.36 & 0.26 & 3 months \\
\hline \multicolumn{4}{|l|}{ Fibrinolytic: } \\
\hline Plasminogen* & 1.95 & 1.70 & 6-12 months \\
\hline Alpha-2-AP* & 0.85 & 0.78 & 3-4 days \\
\hline PAI*\# & 6.40 & 5.40 & 3-4 days \\
\hline $\mathrm{TPA}^{*}$ & 9.60 & 8.48 & 3-4 days \\
\hline
\end{tabular}

Fibrinogen is expressed in $\mathrm{g} / \mathrm{L}$; all the other values are expressed in $\mathrm{U} / \mathrm{mL}$.

F.: factor; HMWK: high molecular weight kininogen; A2M: alpha-2-macroglobulin; alpha-2-AP: alpha-2-antiplasmin;

PAI: plasminogen activator inhibitor; TPA: tissue plasminogen activator.

* Values are different for adults; \# values are different between preterm and term newborn infants. 


\section{CLINICAL PRESENTATIONS}

\section{Venous thrombosis}

Deep vein thrombosis

This is a common condition in patients hospitalized in the Critical Care Unit; its incidence has been reported to be $2-22 \%$. Superior vena caval thrombosis may be asymptomatic or accompanied by edema in the neck, face and/or upper chest, collateral circulation and, eventually, acute heart failure.$^{36} \mathrm{Limb}$ thrombosis may appear as a change in skin color, swelling, edema, pain, elevated temperature and cyanosis. In the case of upper limb involvement, superior vena cava syndrome may also develop. 18,19,26,37,38

Post-thrombotic syndrome is a long-term complication that may develop as a result of neonatal thrombosis, as of one month after the event and up to 10 years later. It is characterized by chronic edema in the limbs together with skin discoloration, impaired wound healing, skin ulcers and, commonly, functional incapacity. It is the result of extravasation of RBCs and inflammatory mediators following damage to venous valves caused by the thrombus. ${ }^{39}$

\section{Renal vein thrombosis}

It accounts for $10 \%$ of venous thrombosis cases in the neonatal period. ${ }^{1,40}$ It is the most common type of thrombosis not related to a central venous catheter. Its clinical presentation starts as a palpable mass in the flank, hematuria, proteinuria, thrombocytopenia, renal failure and/ or arterial hypertension. ${ }^{1,35}$ The classical triad of symptoms -palpable mass, hematuria and renal failure- is seen only in $13 \%$ of patients. ${ }^{41}$ If thrombosis reaches the vena cava (approximately in $50 \%$ of cases), it may also be accompanied by edema, hypothermia and lower limb cyanosis. ${ }^{41-45}$ Approximately $25 \%$ of cases are bilateral. ${ }^{5,46}$

Renal vein thrombosis occurs in the first month of life, generally, in the first three days of life ( $67 \%$ of cases), but it may also develop in utero. $1,13,25,32-35,42,43,47,48$

Risk factors associated with this condition include asphyxia, dehydration, acidosis, arterial hypotension, polycythemia, and maternal diabetes.

Diagnosis is made by Doppler ultrasound, which shows a loss of renal corticomedullary differentiation or, preferably, a color Doppler ultrasound, which allows to observe absence of flow in the involved vein..$^{35,49-51}$

Anticoagulant therapy with unfractionated or low molecular weight heparin has improved survival remarkably, which at present is approximately $85 \%,{ }^{1,40}$ and prevents renal atrophy in two thirds of patients. ${ }^{41}$

\section{Right atrial thrombosis}

It accounts for approximately $6 \%$ of neonatal thromboses. A central venous catheter is present in almost all cases. ${ }^{52}$ Its clinical presentation is variable and includes signs of right-sided heart failure, persistent sepsis, sudden manifestation of murmur, bradycardia, tachyarrhythmia or respiratory distress. ${ }^{1,20}$ The diagnostic method of choice is transthoracic echocardiogram.

Its most serious complications are pulmonary thromboembolism, which becomes apparent due to acute respiratory distress, and stroke.

\section{Arterial thromboses}

Arterial thromboses are, in general, iatrogenic complications of umbilical, peripheral or femoral artery catheterization. Its actual incidence in newborn infants is unknown and varies depending on the method used for assessment: $1-3 \%$ based on clinical signs, $14-35 \%$ based on ultrasonography, and $64 \%$ based on angiography. ${ }^{1,53-56}$

Symptoms depend on thrombus location and size, and may go from no symptoms at all (malfunctioning catheter) to limb-threatening massive ischemia, arterial hypertension with or without renal failure (renal artery occlusion), necrotizing enterocolitis (mesenteric artery occlusion) or even stroke (due to patent foramen ovale). ${ }^{1,57,58}$

The study of choice for this condition in older children and adults is an angiography, but it is not routinely used in newborn infants due to its risks. For this reason, a Doppler ultrasound is generally used to confirm diagnosis, although its actual specificity has not been validated and, in some cases, it may show false negative results. ${ }^{1,2,4,28}$

Its management is a difficult issue. Catheter removal is mandatory, except in isolated exceptional cases. The risk/benefit ratio of using anticoagulant and thrombolytic agents has not been clearly defined, so every case should be assessed individually. ${ }^{1}$ In general, non-occlusive thrombosis may resolve by removing the catheter and with no anticoagulant therapy; however, in the case of significant occlusion, the initial treatment is heparin. ${ }^{4}$ In some specific life-, organ, or limb-threatening circumstances, thrombolytic therapy should be attempted. ${ }^{1}$ 


\section{Stroke}

A stroke may be caused by the occlusion of the arterial flow entering the brain or by the occlusion of its venous drainage system venous sinus thrombosis (VST)-. It typically presents with seizures or lethargy. Focal signs are uncommon, and hemiparesis occurs in less than $25 \%$ of children with ischemic stroke and in less than $10 \%$ of VST cases. ${ }^{4,40,59-64} \mathrm{~A}$ tense anterior fontanelle, diastasis of the cranial sutures and engorged scalp veins in cases of VST have also been observed. ${ }^{40,60,62,65}$

Ischemic stroke diagnosis is confirmed by angiography or angio-MRI. ${ }^{40,66}$ For VST diagnosis, an MRI is the study of choice, but highly satisfactory results have also been observed with transfontanellar Doppler ultrasound and conventional ultrasound. ${ }^{67-70}$

Survival with no neurological sequelae is approximately $33-50 \%{ }^{40,60,71,72}$

Anticoagulant therapy is not recommended for stroke, unless it is a cardioembolic stroke, in which case heparin should be used. ${ }^{40,73}$ For VST with no extensive ischemic areas or intracerebral hemorrhage, heparinization is recommended. In the case of extensive ischemic areas or intracerebral hemorrhage, brain monitoring is necessary, together with anticoagulation if the thrombus increases in size. ${ }^{40,73}$

\section{Purpura fulminans}

This is a very severe condition that should be managed as a medical emergency. It occurs in children with severe protein $C$ deficiency or, less frequently, protein $S$ or antithrombin deficiency. ${ }^{74-76}$ Lesions appear in the capillary vessels of the skin, brain and kidneys because protein $\mathrm{C}$ works mainly in microcirculation.

It s clinical presentation is characteristic. ${ }^{40,74,75,77-81}$ Children with this condition usually have brain and/or ophthalmic damage secondary to intrauterine thrombosis and, in the first hours of life, evidence the complete clinical picture in a catastrophic manner. Skin lesions start as small ecchymoses that gradually extend following a radial pattern, with reddish/blackish color, that turn into bullae and finally become necrotic and gangrenous. Lesions are mainly located in the limbs, but may appear in any other site. The presence of other hemorrhagic manifestations secondary to disseminated intravascular coagulation is practically continuous. Sometimes, large vessel thrombosis may occur.
A definitive diagnosis is based on low or undetectable levels of protein $S$ or $C$, a high suspicion when facing this clinical presentation, and recognition of a heterozygote status in both parents. ${ }^{40,81,82}$

This condition improves with the administration of protein C (60 IU/ kg every 6-8 hours, with a subsequent customized dose adjustment) or, if this approach fails, fresh frozen plasma (10-20 mL/kg every 8-12 hours). For protein $\mathrm{S}$ deficiency, replacement therapy is done using fresh frozen plasma. ${ }^{79,83}$ Treatment is administered until lesions resolve completely, which usually occurs in 6-8 weeks. ${ }^{40}$ Long-term treatment should include oral anticoagulation (maintaining an international normalized ratio [INR] between 2.5 and 4.5) or with low molecular weight heparin $(\mathrm{LMWH})$, together with protein $\mathrm{C}$ (or S) replacement, depending on the patient's symptoms. ${ }^{40,80}$ The option for a definitive cure is liver transplant. ${ }^{40,75}$

\section{TREATMENT}

\section{General management of thromboses}

Asymptomatic thrombosis is managed with supportive care and clot size monitoring. If a central venous catheter is associated with a thrombus, it should be removed. If the thrombus advances, an anticoagulant therapy is required..$^{73}$ Symptomatic thrombosis should be managed with anticoagulant therapy and/or, rarely, thrombolytic agents. If central or umbilical venous catheters are associated with the thrombus, they should be removed, if possible, after three to five days of anticoagulant therapy. ${ }^{73,84}$ When peripheral arterial catheters are associated with thrombosis, they should be removed immediately. ${ }^{73}$ Surgical thrombectomy is rarely indicated in newborn infants because of their small vessels and clinical instability. ${ }^{85}$

\section{Anticoagulant therapy}

Not enough randomized controlled trials have been conducted on anticoagulation in children, so therapeutic schemes used in these patients are based on studies conducted in a small number of cases and guidelines that were adapted from adult treatments. At present, the most commonly used recommendations are evidence-based recommendations provided by experts, considering that most pieces of evidence are grade $2 C^{26,73,86}$

Newborn infants pose two additional hurdles. On one side, it is hard to find an adequate 
venous access to collect the samples necessary for treatment monitoring. On the other side, the milk fed to these newborn infants contains different levels of vitamin $\mathrm{K}$, a complication for oral anticoagulant use.

The most commonly used drugs are unfractionated heparin and LMWH. In general, thrombolytic agents are not recommended, except in life-threatening conditions. New anticoagulant agents are under investigation and cannot be recommended for use in newborn infants.

The optimal duration of treatment has not been clearly established but, in general, it should last between six weeks and three months, depending on the clinical condition. ${ }^{73,87}$

Before starting antithrombotic therapy, prothrombin time, activated partial thromboplastin time (aPTT), platelet and fibrinogen levels should be checked. During anticoagulant therapy, platelet count should be maintained above $50 \times 10^{9} / \mathrm{L}$, while fibrinogen should be over $100 \mathrm{mg} / \mathrm{dl}$. It is also advisable to do a head ultrasound before treatment, especially in preterm infants.

\section{Unfractionated heparin}

Unfractionated heparin enhances antithrombin activity, thereby inactivating thrombin and activated factor $\mathrm{X}(\mathrm{aFX})$. In order to work, an adequate amount of antithrombin is required. Taking into account that, at birth, the level of antithrombin and the ability to generate thrombin are physiologically reduced (even more in preterm infants), sometimes it is necessary to administer antithrombin to reach an adequate anticoagulant response. ${ }^{88,89}$

The initial bolus dose is $75 \mathrm{IU} / \mathrm{kg}$ (10 minutes), followed by a maintenance dose of $28 \mathrm{IU} / \mathrm{kg}$ / hour. The objective is to achieve an anti-aFX level of 0.3-0.7 IU/mL four hours after administration, and an aPTT activity of 1.5-2 times the normal value ${ }^{88,90}$ Once an adequate therapeutic range has been achieved, aPTT and platelet count should be controlled every 24 hours.

The most common secondary effects include bleeding due to an excessive dose and heparininduced thrombocytopenia. If bleeding occurs, discontinue the drug and, if necessary, administer protamine sulfate $(1 \mathrm{mg}$ of protamine per $100 \mathrm{IU}$ of heparin, intravenous infusion over 10 minutes).

The main advantages of unfractionated heparin are its low cost and the fast reversibility of its effect, if necessary, because its half life is one hour.

\section{Low molecular weight heparin}

The advantages of LMWH over unfractionated heparin include subcutaneous administration, a dose administered every 12-24 hours, minimum monitoring requirements, a more predictable response, and a lower risk of bleeding and heparin-induced thrombocytopenia. ${ }^{4}$

The most commonly LMWH used in newborn infants is enoxaparin. For thrombosis management, a $1.5 \mathrm{mg} / \mathrm{kg}$ subcutaneous dose every 12 hours is recommended ${ }^{73}$ however, at present, evidence indicates that the dose required to reach an adequate therapeutic range is approximately $1.7 \mathrm{mg} / \mathrm{kg}$ in term infants and $2 \mathrm{mg} / \mathrm{kg}$ in preterm infants. ${ }^{91}$ The goal is to achieve an anti-aFX level of $0.5-1 \mathrm{IU} / \mathrm{ml}$. For prophylaxis purposes, a half of the therapeutic dose is recommended to reach an anti-aFX level of $0.1-0.3 \mathrm{IU} / \mathrm{ml}$.

\section{Oral anticoagulants}

The most commonly used oral anticoagulants are vitamin $\mathrm{K}$ antagonists, which act by reducing functional activity of vitamin K-dependent coagulation factors (II, VII, IX and X). Considering that these factors are physiologically reduced in newborn infants, using these drugs in infants is problematic, especially given the great variability of vitamin $\mathrm{K}$ in milk, which in turn conditions treatment response: while infant formulas contain vitamin $\mathrm{K}$ supplements to prevent vitamin $\mathrm{K}$ deficiency bleeding, which renders formulafed infants to be relatively resistant to this medication, breast milk contains a very low level of vitamin $\mathrm{K}$, making these infants very sensitive to treatment. ${ }^{1,73,92}$ In addition, this treatment requires frequent monitoring, making it difficult to find adequate venous accesses for sample collection. ${ }^{1}$

Therefore, based on the available evidence, vitamin $\mathrm{K}$ antagonists should be avoided in newborn infants as far as possible. ${ }^{1}$ However, in order to make a decision, it should be considered that maintaining anticoagulation with LMWH for several weeks is an invasive procedure, which sometimes leads to an inadequate treatment adherence. Considering every precaution and with controls done as often as necessary based on the patient's characteristics, oral anticoagulation may be indicated for long-term management. During treatment, special attention should be paid to variations in the type or amount of feeding, infectious complications (especially gastrointestinal complications), and antibiotic 
therapy. ${ }^{3}$ Among exclusively breastfed infants, the low intake of vitamin $\mathrm{K}$ provided by breast milk may be compensated by the administration of prophylactic doses of vitamin $\mathrm{K}$ or small amounts of formula administered on a daily basis. ${ }^{1,73}$

Warfarin or acenocumarol may be used. The recommended initial dose is $0.2 \mathrm{mg} / \mathrm{kg} /$ day to reach an INR between 2 and $3,{ }^{40}$ although it has been observed that the average useful dose for infants is approximately $0.33 \mathrm{mg} / \mathrm{kg} /$ day ${ }^{93}$ If bleeding is caused by an excessive dose, vitamin $\mathrm{K}$ may be administered to neutralize the effect. ${ }^{40}$

An indication of alternative oral anticoagulants, such as argatroban, bivalirudin or fondaparinux, has not yet been established in newborn infants. ${ }^{94}$

\section{Thrombolytic therapy}

Thrombolytic agents generally act by converting plasminogen into plasmin, which acts on fibrin by breaking it down and contributing to thrombus lysis. Since thrombolytic activity may be reduced in these patients due to a decreased plasminogen level, the therapeutic effect of these agents may be limited. Plasminogen supplementation with the administration of fresh frozen plasma may improve fibrinolytic activity.

Considering the high risk of bleeding associated with this treatment, it should be reserved only to infants whose thrombosis is life-, organ-, or limb-threatening. ${ }^{1,95,96}$ It is contraindicated in the following situations: active bleeding, major surgery or bleeding in the previous 10 days, neurosurgery in the previous 3 weeks, severe asphyxia in the previous 7 days, invasive procedure in the previous 3 days, seizures in the past 48 hours, gestational age younger than 32 weeks. ${ }^{97}$

The drug of choice is tissue plasminogen activator (TPA). It is administered in a continuous infusion at a dose of $0.1-0.6 \mathrm{mg} / \mathrm{kg} /$ hour over 6 hours using a central or peripheral line. ${ }^{73}$ No specific lab tests are available to define its therapeutic range or monitoring. A strict clinical, lab and radiological supervision is required. An increase in prothrombin time, aPTT, fibrin degradation products (FDPs) or D-dimer, and a reduction in fibrinogen evidence a response to thrombolytic therapy. It is recommended to maintain fibrinogen values above $100 \mathrm{mg} / \mathrm{dL}$. If bleeding occurs, it is recommended to administer cryoprecipitates $(5-10 \mathrm{~mL} / \mathrm{kg})$ or fibrinogen and, in life-threatening situations, intravenous antifibrinolytics should be added.

Mortality is not clearly defined and varies between $1.2 \%$ and $13 \%$ of patients receiving TPA. ${ }^{98,99}$ Treatment effectiveness with complete clot resolution ranges between $65 \%$ and $94 \% .{ }^{100-102}$

\section{REFERENCES}

1. Greenway A, Massicotte MP, Monagle P. Neonatal thrombosis and its treatment. Blood Rev 2004;18(2):75-84.

2. Schmidt B, Andrew M. Neonatal thrombosis: report of a prospective Canadian and international registry. Pediatrics 1995;96(5 Pt 1):939-43.

3. Donato H. Trastornos trombóticos. In: Donato H, Rapetti MC, eds. Hematología Neonatal. Buenos Aires: Fundasap; 2007.Pages 255-77.

4. Albisetti M, Andrew M, Monagle P. Hemostatic abnormalities. In: De Alarcón P, Werner E, eds. Neonatal hematology. New York: Cambridge University Press; 2005. Pages 310-48.

5. Hilario Barrio A, Gallego Herrero C, Miralles Molina M, Medina López C, et al. Trombosis venosa renal neonatal: diagnóstico precoz con ecografía Doppler y secuelas a largo plazo. Radiología 2009;51(6):583-90.

6. O'Neill JA Jr, Neblett WW 3rd, Born ML. Management of major thromboembolic complications of umbilical artery catheters. J Pediatr Surg 1981;16(6):972-8.

7. Olinsky A, Aitken FG, Isdale JM. Thrombus formation after umbilical arterial catheterisation. An angiographic study. S Afr Med J 1975;49(36):1467-70.

8. Oppenheimer DA, Carroll BA, Garth KE. Ultrasonic detection of complications following umbilical arterial catheterization in the neonate. Radiology 1982;145(3): 66772.

9. Horgan MJ, Bartoletti A, Polansky S, Peters JC, et al. Effect of heparin infusates in umbilical arterial catheters on frequency of thrombotic complications. I Pediatr 1987;111(5):774-8.

10. Seibert JJ, Taylor BJ, Williamson SL, Williams BJ, et al. Sonographic detection of neonatal umbilical-artery thrombosis: clinical correlation. AJR Am J Roentgenol 1987;148(5):965-8.

11. Andrew M. Developmental hemostasis: relevance to newborns and infants. In: Nathan DG, Orkin SH, Oski FA, eds. Nathan and Oski's Hematology of Infancy and Childhood. 5th ed. Philadelphia: WB Saunders; 1998. Pages 114-58.

12. Donato H. Hemostasia normal en el feto y el recién nacido. In: Donato H, Rapetti MC, eds. Hematología Neonatal. Buenos Aires: Fundasap; 2007. Pages 195-205.

13. Nowak-Göttl U, Von Kries R, Göbel U. Neonatal symptomatic thromboembolism in Germany: two year survey. Arch Dis Child Fetal Neonatal Ed 1997;76(3):F163-7.

14. SchmidtB,Zipursky A. Thrombotic diseaseinnewborninfants. Clin Perinatol 1984;11(2):461-88.

15. KhilnaniP, Goldstein B, Todres ID. Doublelumen umbilical venous catheters in critically ill neonates: a randomized prospective study. Crit Care Med 1991;19(11):1348-51.

16. Andrew M, David M, Adams M, Ali K, et al. Venous thromboembolic complications (VTE) in children: first analyses of the Canadian Registry of VTE. Blood 1994;83(5):1251-7.

17. Monagle P, Adams M, Mahoney M, Ali K, et al. Outcome of pediatric thromboembolic disease: a report from the Canadian Childhood Trombophilia Registry. Pediatr Res 2000;47(6):763-6.

18. AmentJ,NewthCJ.Deepvenouslinesand thromboembolism. Pediatr Pulmonol 1995;20(6):347-8.

19. Marie I, Lévesque H, Cailleux N, Primard E, et al. Les thromboses veineuses profondes des membres supérieurs. À propos de 49 cas. Rev Med Interne 1998;19(6):399-408.

21. Kramer SS, Taylor GA, Garfinkel DJ, Simmons MA. Lethal 
chylothoraces due to superior vena caval thrombosis in infants. AJR Am J Roentgenol 1981;137(3):559-63.

22. Le Coultre C, Oberhänsli I, Mossaz A, Bugmann P, et al. Postoperative chylothorax in children: differences between vascular and traumatic origin. J Pediatr Surg 1991;26(5): 519-23.

23. Andrew M,Paes B, Milner R, Johnston M, etal. Development of the human coagulation system in the full-term infant. Blood 1987;70(1):165-72.

24. Andrew M,Paes B, Milner R, Johnston M, etal. Development of the human coagulation system in the healthy premature infant. Blood 1988;72(5):1651-7.

25. Tinaztepe K, Buyan N, Tinaztepe B, Akkök N. The association of nephrotic syndrome and renal vein thrombosis: a clinic pathological analysis of eight pediatric patients. Turk J Pediatr 1989;31(1):1-18.

26. Mulvihill SJ, Fonkalsrud EW. Complications of superior versus inferior vena cava occlusion in infants receiving central total parenteral nutrition. J Pediatr Surg 1984;19(6):752-7.

27. Mitchell L, ChaitP, Ginsberg J. Comparison of venography with ultrasound for the detection of venous thrombosis in the upper body in children: results of the PARKAA study. Blood 1999;94(Suppl 1):588a.

28. Edstrom CS, Christensen RD, Andrew M. Developmental aspects of blood hemostasis and disorders of coagulation and fibrinolysis in the neonatal period. In Christensen RD, ed. Hematologic problems of the Neonate. Philadelphia: Saunders; 2000. Pages 239-72.

29. Kurekci E, Kaye R, Koehler M. Chylothorax and chylopericardium: a complication of a central venous catheter. J Pediatr 1998;132(6):1064-6.

30. Barnes C, Newall F, MonagleP. Post-thrombotic syndrome. Arch Dis Child 2002;86(3):212-4.

31. Andrew M, Brooker LA. Hemostatic disorders in newborns. In:Polin R, FoxW, AbmanS, eds. Fetal and neonatal physiology. 2nd ed. Philadelphia: WB Saunders; 1998. Pages 1803-33.

32. Reverdiau-Moalic P, Delahousse B, Body G, Bardos P, et al. Evolution of blood coagulation activators and inhibitors in the healthy fetus. Blood 1996;88(3):900-6.

33. Nuss R, Hays T, Manco-Johnson M. Efficacy and safety of heparin anticoagulation for neonatal renal vein thrombosis. Am J Pediatr Hematol Oncol 1994;16(2):127-31.

34. WrightNB, Blanch G, Walkinshaw S, Pilling DW. Antenatal and neonatal renal vein thrombosis: new ultrasonic features with high frequency transducers. Pediatr Radiol 1996;26(9):686-9.

35. Andrew M, Monagle P, Brooker L. Thromboembolic complications during infancy and childhood. Hamilton BC: DeckerInc; 2000. Chapter 8, Thromboembolic complications in specific organ sites and pediatric diseases; Pages 231-76.

36. Ladino M, Ruiz-Esquide F, Guardia S. Trombosis venosa profunda en relación a un catéter central: edema neonatal en esclavina, un caso clínico. Rev Chil Pediatr 2001;72(4): 340-4.

37. Rockoff MA, Gang DL, Vacanti JP. Fatal pulmonary embolism following removal of a central venous catheter. J Pediatr Surg 1984;19(3):307-9.

38. Derish MT, Smith DW, Frankel LR. Venous catheter thrombus formation and pulmonary embolism in children. Pediatr Pulmonol 1995;20(6):349-54.

39. Sharathkumar AA, PipeSW. Post-thrombotic syndrome in children: a single center experience. J Pediatric Hemat Oncol 2008;30(4):261-6.

40. Monagle P, Chan A, Massicotte P, Chalmers E, et al. Antithrombotic therapy in children: the Seventh ACCP Conference on Antithrombotic and Thrombolytic Therapy. Chest 2004;126(3 Suppl):645S-87S.

41. Zigman A, Yazbeck S, Emil S, Nguyen L. Renal vein thrombosis: a 10-year review. J Pediatr Surg 2000;35(11): 1540-2.

42. Lalmand B, Avni EF, Nasr A, Ketelbant P, et al. Perinatal renal vein thrombosis: Sonographic demonstration. J Ultrasound Med 1990;9(8):437-42.

43. Duncan BW, Adzick NS, Longaker MT, Edwards JR, et al. In utero arterial embolism from renal vein thrombosis with successful postnatal thrombolytic therapy. J Pediatr Surg 1991;26(6):741-3.

44. Brill PW, Jagannath A, Winchester P, Markisz JA, et al. Adrenal hemorrhage and renal vein thrombosis in the newborn: MR imaging. Radiology 1989;170(1 Pt 1):95-8.

45. Laplante S, Patriquin HB, Robitaille P, Filiatrault D, et al. Renal vein thrombosis in children: evidence of early flow recovery with Doppler US. Radiology 1993;189(1):37-42.

46. Marks SD, Massicotte MP, Steele BT, Matsell DG, et al. Neonatal renal venous thrombosis: clinical outcomes and prevalence of prothrombotic disorders. J Pediatr 2005;146(6):811-6.

47. Sanders LD, JequierS. Ultrasound demonstration of prenatal renal vein thrombosis. Pediatr Radiol 1989;19(2):133-5.

48. Cozzolino DJ, Cendron M. Bilateral renal vein thrombosis in a newborn: a case of prenatal renal vein thrombosis. Urology 1997;50(1):128-31.

49. Greene A, Cromie WJ, Goldman M. Computerized body tomography in neonatal renal vein thrombosis. Urology 1982;20(2):213-5

50. Cremin BJ, Davey H, Oleszczuk-Raszke K. Neonatal renal venous thrombosis: sequential ultrasonic appearances. Clin Radiol 1991;44(1):52-5.

51. Hibbert J, Howlett DC, Greenwood KL, MacDonald LM, et al. The ultrasound appearances of neonatal renal vein thrombosis. Br J Radiol 1997;70(839):1191-4.

52. Avila ML,Solana CL, Laura JP,Suárez J,etal.Trombectomía auricular derecha en un recién nacido prematuro de muy bajo peso. Arch Arg Pediatr 2006;104(3):272-4.

53. Downs JB, Chapman RLJr, Hawkins IF Jr. Prolonged radial artery catheterization. An evaluation of heparinized catheters and continuous irrigation. Arch Surg 1974;108(5):671-3.

54. Hoar PF, Wilson RM, Mangano DT, Avery GJ 2nd, et al. Heparin bonding reduces thrombogenicity of pulmonaryartery catheters. N C Med I 1981;305(17):993-5.

55. American Association of Critical-Care Nurses. Evaluation of the effects of heparinized and nonheparinized flush solutions on the patency of arterial pressure monitoring lines: the AACN Thunder Project. Am J Crit Care 1993;2(1): 3-15.

56. Cohen RS, Ramachandran P, Kim EH, Glasscock GF. Retrospective analysis of risks associated with an umbilical artery catheter system for continuous monitoring of arterial oxygen tension. J Perinatol 1995;15(3):195-8.

57. Bryant BG. Drug, fluid, and blood products administered through the umbilical artery catheter: complication experiences from one NICU. Neonatal Netw 1990;9(1):27-32.

58. Glickstein JS, Rutkowski M, Schacht R, Friedman D. Renal blood flow velocity in neonates with and without umbilical artery catheters. J Clin Ultrasound 1994;22(9):543-50.

59. De Veber G. Canadian paediatric ischemic stroke registry: analysis of children with arterial ischemic stroke. Ann Neurol 2000;48(3):526a.

60. Barron TF, Gusnard DA, Zimmerman RA, Clancy RR. Cerebral venous thrombosis in neonates and children. Pediatr Neurol 1992;8(2):112-6.

61. Shevell MI, Silver K, O'Gorman AM, Watters GV, et al. Neonatal dural sinus thrombosis. Pediatr Neurol 1989;5(3):161-5.

62. Rivkin MJ, Anderson ML, Kaye EM. Neonatal idiopathic cerebral venous thrombosis: an unrecognized cause of transient seizures or lethargy. Ann Neurol 1992;32(1):51-6.

63. De Veber G, Adams M, Andrew M. Neonatal cerebral thromboembolism: clinical and radiographic features. Thromb Haemostas 1997;78(Suppl):725.

64. De Veber G, Andrew M, Adams C, Bjornson B, et al. Cerebral sinovenous thrombosis in children. $N$ C Med J 2001;345(6):417-23. 
65. De Veber G, Andrew M. Canadian Pediatric Ischemic Stroke Registry: analysis I. Pediatr Res 1994;35:379a.

66. Lynch JK, Hirtz DG, De Veber G, Nelson KB. Report of the National Institute of Neurological Disorders and Stroke workshop on perinatal and childhood stroke. Pediatrics 2002;109(1):116-23.

67. Macchi PJ, Grossman RI, Gomori JM, Goldberg HI, et al. High field MR imaging of cerebral venous thrombosis. J Comput Assist Tomogr 1986;10(1):10-5.

68. Zimmerman RA, Bogdan AR, Gusnard DA. Pediatric magnetic resonance angiography: assessment of stroke. Cardiovasc Intervent Radiol 1992;15(1):60-4.

69. Medlock MD, Olivero WC, Hanigan WC, Wright RM, et al. Children with cerebral venous thrombosis diagnosed with magnetic resonance imaging and magnetic resonance angiography. Neurosurgery 1992;31(5):870-6.

70. Bezinque SL, Slovis TL, Touchette AS, Schave DM, et al. Characterization of superior sagittal sinus blood flow velocity using color flow Doppler in neonates and infants. Pediatr Radiol 1995;25(3):175-9.

71. De Veber GA, MacGregor D, Curtis R, Mayank S. Neurologic outcome in survivors of childhood arterial ischemic stroke and sinovenous thrombosis. JChild Neurol 2000;15(5):316-24.

72. De Veber G, Adams M, Andrew M. Canadian Pediatric Ischemic Stroke Registry (analysis III). Can J Neurol Sci 1995;22(Suppl):S24a.

73. Monagle P, Chan AK, Goldenberg NA, Ichord RN, et al. Antithrombotic therapy in neonates and children: Antithrombotic Therapy and Prevention of Thrombosis, $9^{\text {th }}$ ed. American College of Chest Physicians EvidenceBased Clinical Practice Guidelines. Chest 2012;141(2Suppl): e737S- e801S.

74. Adcock DM, Brozna J, Marlar RA. Proposed classification and pathologic mechanisms of purpurafulminans and skin necrosis. Semin Thromb Hemost 1990;16(4):333-40.

75. Marlar RA, Montgomery RR, Broekmans AW. Diagnosis and treatment of homozygous protein $C$ deficiency. Report of the Working Party on Homozygous Protein C Deficiency of the Subcommittee on Protein C and ProteinS, International Committee on Thrombosis and Haemostasis. J Pediatr 1989;114(4 Pt 1):528-34.

76. Mahasandana C, Suvatte V, Chuansumrit A, Marlar RA, et al. Homozygous protein $S$ deficiency in an infant with purpurafulminans. J Pediatr 1990;117(5):750-3.

77. Auletta MJ,HeadingtonJT.Purpurafulminans. A cutaneous manifestation of severe protein C deficiency. Arch Dermatol 1988;124(9):1387-91.

78. Adcock DM, Hicks MJ. Dermatopathology of skin necrosis associated with purpura fulminans. Semin Thromb Hemost 1990;16(4):283-92.

79. Marlar RA, Neumann A. Neonatal purpura fulminans due to homozygous protein $\mathrm{C}$ or protein $\mathrm{S}$ deficiencies. Semin Thromb Hemost 1990;16(4):299-309.

80. Andrew M, Monagle P, Brooker L. Thromboembolic complications during infancy and childhood. Hamilton BC: Decker Inc; 2000. Chapter 3, Congenital prothrombotic disorders: presentation during infancy and childhood; Pages 47-110.

81. Williams MD, Chalmers EA, Gibson BE. The investigation and management of neonatal haemostasis and thrombosis. Br J Haematol 2002;119(2):295-309.

82. Dreyfus M,MagnyJF, Bridey F,SchwarzHP, etal. Treatment of homozygous protein $C$ deficiency and neonatal purpura fulminans with a purified protein C concentrate. NCMed J 1991;325(22):1565-8.

83. Chalmers EA. Neonatal thrombosis. J Clin Pathol 2000;53(6):419-23.

84. Edstrom CS, Christensen RD. Evaluation and treatment of thrombosis in the neonatal intensive care unit. Clin Perinatol 2000;27(3):623-41.

85. Lin PH, Dodson TF, Bush RL, Weiss VJ, et al. Surgical intervention for complications caused by femoral artery catheterization in pediatric patients. J Vasc Surg 2001;34(6):1071-8.

86. Altuna D. Trombosis en pediatría. Hematología (B Aires) 2013;17:38-43.

87. Dix D, Andrew M, Marzinotto V, Charpentier K, et al. The use of low molecular weight heparin in pediatric patients: a prospective cohort study. J Pediatric 2000;136(4):439-45.

88. Andrew M, Marzinotto V, Massicotte P, Blanchette V, et al. Heparin therapy in pediatric patients: a prospective cohort study. Pediatric Res 1994;35(1):78-83.

89. Andrew M, Ofosu F, Schmidt B, Brooker L, et al. Heparin clearance and ex vivo recovery in newborn piglets and adult pigs. Thromb Res 1988;52(6):517-27.

90. Schmidt B, Buchanan MR, Ofosu F, Brooker L, et al. Antithrombotic properties of heparin in a neonatal piglet model of thrombin-induced thrombosis. Thromb Haemost 1988;60(2):289-92.

91. Streif W, Goebel G, Chan AK, Massicotte MP. Use of low molecular mass heparin (enoxaparin) in newborn infants: a prospective cohort study of 62 patients. Arch Dis Child Fetal Neonatal Ed 2003;88(5):F365-70.

92. Andrew M, Monagle P, Brooker L. Thromboembolic complications during infancy and childhood. Hamilton BC: Decker Inc; 2000. Chapter 9, Oral anticoagulation therapy in pediatric patients; Págs.278-356.

93. Streif W, Andrew M, Marzinotto V, Massicotte P, et al. Analysis of warfarin therapy in pediatric patients: a prospective cohort study of 319 patients. Blood 1999;94(9):3007-14.

94. Young G. Old and new antithrombotic drugs in neonates and neonates and infants. Semin Fetal Neonatal Med 2011;16(6):349-54.

95. Monagle P, Michelson AD, Bovill E, Andrew M. Antithrombotic therapy in children. Chest 2001;119(1 Suppl):344S-370S.

96. Ries M, Easton RL, LongstaffC, Zenker M, et al. Differences between neonates and adults in tissue-type-plasminogen activator ( $\mathrm{t}-\mathrm{PA}$ ) catalyzed plasminogen activation with various effectors in carbohydrate sequences of fibrinogen chains. Thromb Res 2001;103(3):173-84.

97. Manco-Johnson MJ, Grabowski EF, Hellgreen M, Khemali AS, et al. Recommendations for tPA thrombolysis in children. On behalf of the Scientific Subcommittee on Perinatal and Pediatric Thrombosis of the Scientific and Standardization Committee of the International Society of Thrombosis and Haemostasis. Thromb Haemost 2002;88(1):157-8

98. Zenz W, Arlt F, Sodia S, Beghold A. Intracerebral hemorrhage during fibrinolytic therapy in children: a review of the literature of the last thirty years. Semin Thromb Hemost 1997;23(3):321-32.

99. Farnoux C, Camard O, Pinquier D, Hurtaud-Roux MF, et al. Recombinant tissue-type plasminogen activator therapy of thrombosis in 16 neonates. J Pediatr 1998;133(1):137-40.

100.Zenz W, Muntean W, Beitzke A, Zobel G, et al. Tissue plasminogen activator (alteplase) treatment for femoral artery thrombosis after cardiac catheterisation in infants and children. Br Heart J 1993;70(4):382-5.

101.Andrew M, Monagle P, Brooker L. Thromboembolic complications during infancy and childhood. Hamilton BC: Decker Inc; 2000. Chapter 10, Thrombolytic therapy; p. 357-84.

102.Browne M, Newall F, Campbell J, Savoia HF, et al. Thrombolytic therapy with tissue plasminogen activator (tPA), analysis of safety and outcome in children. J Thromb Haemost 2003;1(Suppl 1):P1488. 